ONDERZOEKSRAPPORT NR. 8805

\title{
THE FORMATION OF THE EUROPEAiN COMMON MARKET AND CHANGES IN MARKET STRUCTURE AND PERFORMANCE
}

BY

L. SLEUWAEGEN \& H. YAMAWAKI

D/1988/2376/6 


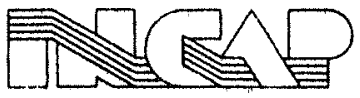

INdustry and Company Analysis Frogram

Katholieke Universiteit Leuven

Departement voor Toegepaste Economische Wetenschappen

Dekenstraat 2

B-3000 Leuven 016/22.75.17

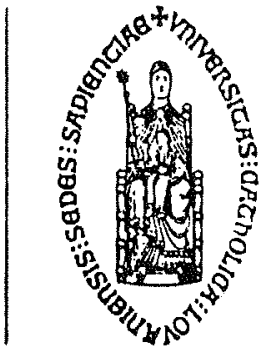

The Formation of the European Common Market and Changes in Market Structure and Performance

by

\author{
Leo Sleuwaegen* \\ Q
}

Hideki Yamawaki * *

January 1988

* Catholic University of Leuven INCAP

Dekenstraat 2, B-3000 Leuven

Belgium

* * Science Center Berlin

International Institute of Management

Platz der Luftbrïcke 2

D-1000 Berlin 42

West Germany

This paper draws on continuing research carried out jointly with Leonard $w$. Weiss and uses part of the results obtained there, for which we are grateful to him. We are also grateful to Richard E. Caves and Alexis P. Jacquemin for helpful comments and suggestions on earlier drafts. We thank $W$. Knuppel of the statistical office of the European Communities for providing access to the data base employed for this project. 
Abstract

This paper examines the effects of the formation of the Common Market on changes in seller concentration and price-cost margins in the member states. Using NACE 3-digit industry data for West Germany, France, Italy, Belgium, and the Netherlands, the paper first seeks to identify the effect of the removal of intra-EC tariffs on changes in national concentration. The paper then tests the hypothesis that concentration measured at the EC-wide level is becoming a relevant structural variable which affects the national price-cost margin. 


\section{Introduction}

The removal of tariffs and quantitative restrictions on trade which created a common market known as the European Economic Community $(E E C)^{1}$ provides researchers a great opportunity for studying its effects on economic variables. One research area which has been most intensively analyzed so far is the effects of the formation of the Common Market on international trade flows. Attempts to estimate trade creation and trade diversion abound and have found that in the Common Market trade creation exceeded trade diversion. ${ }^{2}$ Also it has been observed that the creation of the Common Market caused an increase in intraindustry trade among the Common Market countries. ${ }^{3}$

However, surprisingly little attention has been paid on the effects of the Common Market's formation on market structure and competitive performance in the member countries. The liberalization of trade among the EC countries leads to a number of interesting hypotheses concerning the dynamic adjustments of market structure and performance. One of the important hypotheses on the effect of the Common Market's formation on market structure is that the elimination of tariffs and other restrictions on trade increased the industry's exposure to trade and thus led to rationalization of inefficient-size plants which had not exploited scale economies in the national market. ${ }^{4}$ Correspondingly, seller concentration in the national market should have been changed after the formation of the Common Market.

Another interesting hypothesis, which relates the formation of the Common Market to changes in market behavior and 
performance, is that domestic sellers in a member country may start to recognize interdependence with foreign sellers in another member country and engage in an oligopoly game after the formation of the EC as they now meet and compete with each other in the Common Market. To the extent that this is the case, market perfomance of each community member would be affected by the state of community-wide competition which may be represented by seller concentration on a community-wide basis. A measure of EC-wide concentration, which is supposed to capture the effect of the enlarged market, has been proposed and estimated by Yamawaki, Weiss, and sleuwaegen (1987).

The purpose of the paper is therefore twofold: First, we examine the effects of the massive elimination of tariffs effected by the EC on changes in seller concentration for each member of the Common Market; and secondly, we test the hypothesis that EC-wide concentration will be a significant element of market structure which affects the member country's price-cost margin in industries where the integration of markets is more complete. Thus, in section II we report the statistical results of the determinants of changes in seller concentration. After we briefly explained the method to estimate a measure of EC-wide concentration, we report in Section III the regression results which explain changes in price-cost margins by EC-wide concentration. Finally, section IV concludes the paper. 
II. The Formation of the Common Market and Changing Industrial Concentration in the Member states

It is a well-documented fact that the liberalization of trade among the member states of the European Community (EC) which created a customs union has greatly increased intraCommunity trade. The increase in intra-EC trade in manufacturing has been caused mainly by trade creation (the displacement of domestic production of imported goods by imports from more competitive EC countries) and not by trade diversion (the replacement of imports from a low cost extra-EC source by imports from a less efficient intra-EC source). Furthermore, this has been reinforced by a rising importance of intra-industry trade and a substantial improvement in the efficiency of European industries relative to the counterparts in the rest of the world (Balassa, 1975).

\section{II-1. A Hypothesis}

One hypothesis which emerges from this observation is that the increasing trade exposure after the removal of tariffs and other restrictions of trade within the EC gave rise to adjustments of the structure of industries in the member states of the Common Market. It should be noted, however, that the increasing extra-EC trade exposure effected by the different GATT rounds which took place in the same periods may have caused similar adjustments in market structures (see Jacquemin and Sapir, 1988).

The effects of the elimination of tariffs and increased trade exposure on changes in industrial concentration are difficult to formulate a priori in the framework of a formal 
theoretical model. Instead, we start our analysis by asking an empirical question whether the enlargement of market sizes through the removal of intra-Community tariffs has led to competitive displacement of inefficient-scale producers by a producer who builds an efficient-scale plant and seeks to exhaust available economies of scale. Correspondingly, seller concentration in the national market should be increased after the elimination of intra-Community tariffs. (Scitovsky, 1958; Owen, 1983; and Caves, 1985). The assumption underlying this hypothesis is that in the pre-EC period market behavior in the national market is that of a collusive oligopoly, and the national oligopolists discourage themselves from expanding their production capacities. When tariff barriers are eliminated and more effecient foreign producers try to sell their goods at more competitive prices within the Common Market, the domestic oligopolists respond by expanding their capacities and trying to exploit available scale economies. With the price depressed, inefficient-scale domestic producers will be forced to exit in the adjustment process (Caves, 1985).

\section{II-2. Statistical Analysis}

\section{Variables and Data}

Using a statistical model, we test the hypothesis that the elimination of intra-EC tariffs has increased seller concentration in the national market of the member states. Thus, our main concern is to examine the effect of changes in tariffs on changes in national concentration. The removal of tariffs within the EC is interpreted in our analysis as the 
change of tariffs from the pre-EC level to the post-EC level which is zero.

Our research design and the choice of observation period were mainly governed by the scarcity of data, especially seller concentration. Since seller concentration at a disaggregated industry level which is comparable among the original members of the EC is not easily obtainable from published sources, we estimated them from the first EC Census which was published for 1963 and the unpublished data for 1978 which were made available to us by the statistical office of the European Communities. Correspondingly, all other variables except the tariff variable in the statistical analysis are constructed around these two years and expressed in a change form. Although it was dictated by data limitations, the choice of 1963 as the beginning year of the observation period is not satisfactory since the tariff reduction process in the EC started in 1959. However, given the facts that 1963 was in the middle of the tariff reduction process which ended in 1968,5 and market structure tends to change rather slowly, 6 it may not be particularly unreasonable to represent the pre-EC market structure by the market structure in 1963 and assume that they belonged to the same regime.

The data for 1963 and 1978 are available at the three-digit level of the EC Industrial Classification. ${ }^{7}$ We eliminated 56 industries from the entire sample since some figures for these industries are omitted for disclosure reasons. Thus, our sample consists of 47 three-digit industries matched among the EC countries.

Our dependent variable is the change in concentration: 


$$
\begin{aligned}
\Delta L N C R 4= & \operatorname{LNCR} 4(78)-\operatorname{LNCR} 4(63)=\text { Change in the logarithm of } \\
& \text { the four-firm national concentration (LNCR4) } \\
& \text { between } 1978 \text { and } 1963 .
\end{aligned}
$$

National concentration (NCR4) was estimated from data on the firm size distribution by employment size class for the EC countries. The estimation method was originated by Bain (1966) and has been employed by Phlips (1971), George and Ward (1975), and Owen (1983).8 The concentration ratio is measured in terms of employment instead of sales due to data limitation. ${ }^{9}$

We test our hypothesis on the concentration increasing effect of the removal of tariffs by the change in intra-EC tariffs:

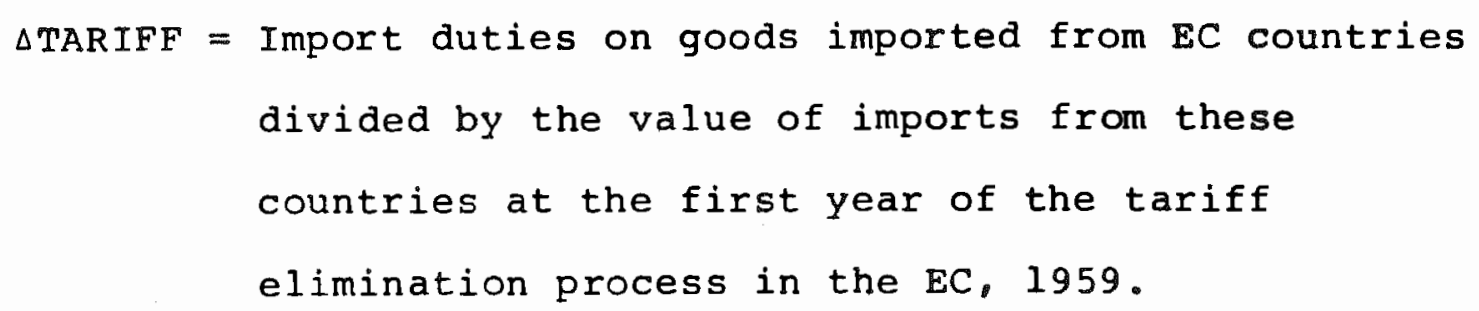

Since all the intra-EC tariffs were elimiated by 1968, $\triangle$ TARIFF represents the absolute percentage reduction of intra-EC tariffs for each member country. This variable measures the direct impact of the intra-EC trade liberalization through the formation of a customs union. However, this variable measures only the effect of tariffs but not the role of non-tariff barriers to trade. Thus, we expect a positive relation between $\triangle$ INCR4 and $\triangle$ TARIFF, implying that the tariff reduction increases concentration. 
To capture the effect of the Common Market's formation, we prefer the use of the tariff variable to the use of changes in trade intensity since the trade variables do not distinguish the increase in trade flows due to the tariff elimination from the increase due to other disturbances and therefore measure the effect of the trade liberalization only imperfectly. Furthermore, the use of trade intensity variables may suffer from an econometric simultaneity problem in so far as they are jointly determined with market structure (Lyons, 1987). Nevertheless, we include the trade intensity variables to control for the observed effects of trade liberalization. ${ }^{10}$ The change in exports is measured by

$$
\begin{aligned}
\Delta W X S= & \text { WXS }(78)-W X S(63)=\text { Change in export intensity (WXS) } \\
& \text { between } 1978 \text { and } 1963 \text {. Export intensity is measured } \\
& \text { as the ratio of total exports to total shipments. }
\end{aligned}
$$

The change in imports is measured by

$$
\begin{aligned}
\Delta W M S= & \text { WMS }(78)-\text { WMS }(63)=\text { Change in import intensity (WMS) } \\
& \text { between } 1978 \text { and } 1963 \text {. Import intensity is measured } \\
& \text { by the ratio of total imports to apparent domestic } \\
& \text { consumption (total shipments + imports - exports). }
\end{aligned}
$$

Besides the change in exports and the change in imports, we include a variable which represents changes in the size of industry: 


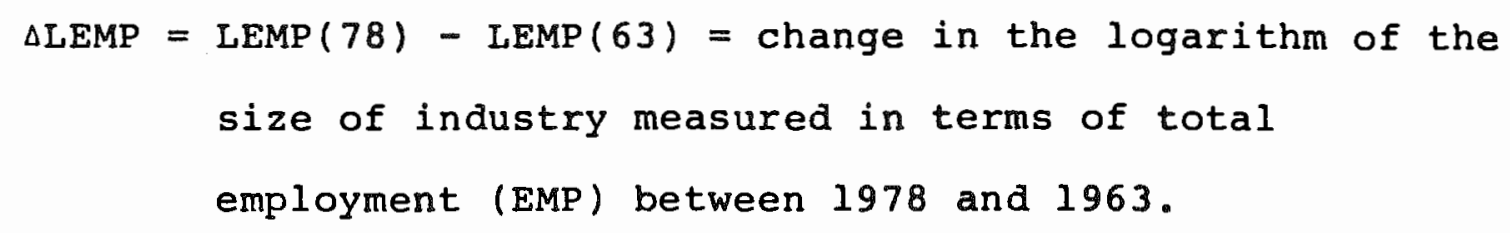

In an effort to control for the effect of changes in the size of efficient-scale plants on changes in concentration, we use

$$
\begin{aligned}
\Delta L P S= & \operatorname{LPS}(78)-\operatorname{LPS}(66)=\text { Change in the logarithm of } \\
& \text { average plant size (PS) between } 1978 \text { and } 1966 .
\end{aligned}
$$

This variable is supposed to represent changes in the technological conditions related to scale economies. With the size of industry controlled, increases in average plant size due to changes in minimum efficient scale will raise concentration. 11

other variables included in the statistical model are as follows :

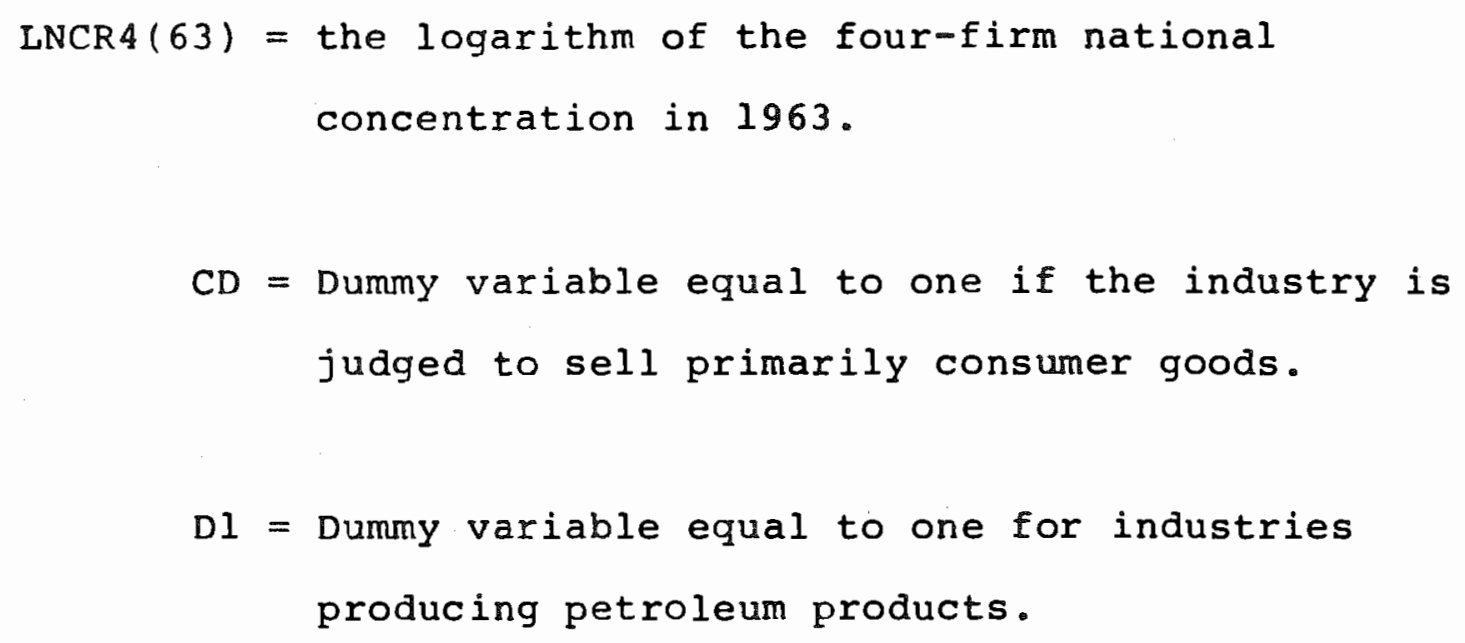




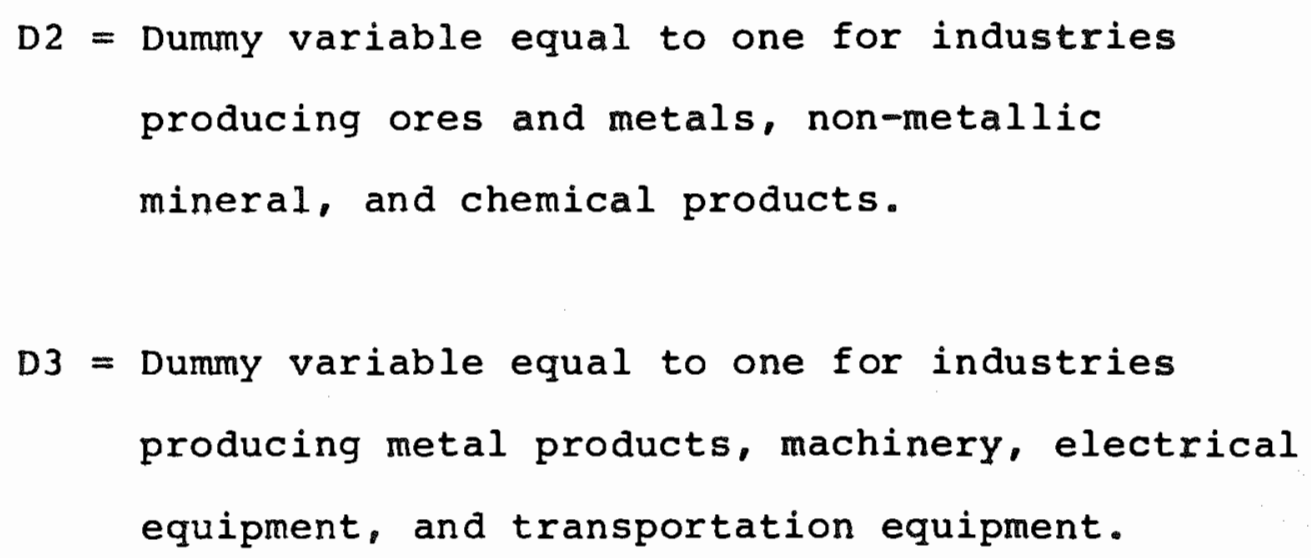

LNCR4 (63) is included to provide a control for the initial level of concentration since changes in concentration would be constrained by the initial level. $C D$ is intended to control for product characteristics and designate industries where product differentiation based on consumer tastes plays an important role. Other three dummy variables, D1, D2, and D3, also control for industry characteristics. Those industries which are not represented by these dummies are taken as the reference sector.

We estimate the following model for five Common Market countries, namely West Germany, France, Italy, Belgium, and the Nether 1 ands: 12

$$
\begin{aligned}
\Delta \text { LNCR4 }= & a_{0}+\sum_{i=1}^{3} a_{i} D(i)+a_{4} \text { CD }+a_{5} \Delta \text { TARIFF } \\
& +a_{6} \Delta \text { WXS }+a_{7} \Delta \text { WMS }+a_{8} \Delta \text { LEMP }+a_{9} \Delta \text { LPS } \\
& +a_{10} \text { LNCR4 }(63)+\mu
\end{aligned}
$$

where $\mu$ is the disturbance term. Table 1 presents means and standard deviations of the variables used in the statistical analysis. The table shows that in our sample the magnitude of the reduction of intra-EC tariffs for France, 0.22 , is the largest among the five countries and followed by Italy, 0.19 , 
and Belgium, 0.13. The change in concentration is again the largest for France, which is again followed by Italy and Belgium. Detailed accounts on the data sources are given in the appendix.

\section{Statistical Results}

The OLS result of equation (1) which is estimated separately for the five EC countries is presented in Table 2-A to table 2-F. In table 2, equation 1 shows the result without the tariff and trade exposure variables while equations 2 and 3 include either of these variables. Equation 4 in table 2 includes the tariff and trade variables together. In equations 5 and 6 , the coefficients for $\triangle W X S$ and $\triangle W M S$ are constrained to be equal, $a_{6}=a_{7}$, in order to measure total trade exposure or the openness of the industry.

our main hypothesis on the concentration increasing effect of tariff reductions is tested in equations 2 and $4 . \triangle T A R I F F$ has a significant and expected positive coefficient in all the countries except the Netherlands. For West Germany, France, and Belgium, the significant positive effect of $\triangle$ TARIFF remains unchanged even after $\triangle$ WXS and $\triangle$ WMS are included in equation 4. Thus, the finding suggests that the elimination of intra-EC tariffs have promoted a more concentrated industry structure in the EC countries except the Netherlands. This may further imply that a strong shake-out of inefficient-scale plants and a better exploitation of scale economies in the larger firms have been realized after the formation of the Common Market. ${ }^{13}$

The sign of the coefficient for $\triangle$ TARIFF in the Netherlands is negative but insignificantly different from zero at the 
10 percent level of significance. It should be noted that the Netherlands display the lowest mean reduction of intra-EC tariffs, 0.05 , with smaller variation across the sample industries, 0.02, which make a marked contrast with the French figures where the mean is 0.22 with the standard deviation of 0.08 .

In estimating the effect of the tariff variable, we found the estimation results for France to be very sensitive to the inclusion of textiles and clothing industries where the pre-EC levels of tariffs were quite high. Import duties as a ratio to the value of intra-EC imports for the textiles and clothing industries in France are 0.266 and 0.324 respectively, which are about 7 times as high as those for the counterparts in the Netherlands and more than 2.5 times as high as those for West Germany. When industries in the two sectors are excluded from the sample, the coefficient for $\triangle T A R I F F$ in France becomes highly significant at the 1 percent level with a positive sign as seen in equations 2 and 4 in table $2-C$, suggesting that these two industries are outliers in the sample. This result seems to reflect the fact that the concentration increasing effect of the massive removal of intra-EC tariffs in the textiles and clothing sectors is offset by the imposition of quotas which renders the internal customs union ineffective. (Pelkmans, 1984, pp. 244-245).14

The effects of the trade variables, $\triangle$ WXS and $\triangle W M S$, tend to vary from one country to another in unconstrained equations 3 and 4 . To see whether the coefficient on $\Delta$ WXS is equal to that on $\triangle W M S$, we estimated the equation with the restriction on their coefficients. With the coefficients of the two trade 
exposure variables constrained to the same value lequations 5 and 6 ), the restriction can not be rejected at the 10 percent level of significance for all countries except Belgium. In equations 5 and 6 , the constrained coefficient is negative and significant for all five countries, implying that total trade exposure decreases domestic concentration. Thus, the more open the industry becomes, the less the industry becomes concentrated, suggesting that total trade exposure brings about a more equal distribution of company sizes in the industry.

That this concentration decreasing effect of observed trade exposures needs to be distinguished from the concentration increasing effect of the elimination of tariffs is illustrated clearly in equation 6 . In this fully specified equation, for West Germany, France, and Belgium, the coefficient of the change in tariffs remains positive and unaffected by the inclusion of the trade intensity variables.

The rest of the variables in the equation show the effects which are consistent across the five EC countries. The change in the size of industry, $\triangle$ LEMP, and the initial level of national concentration, LNCR4(63), have significant and expected negative effects on changes in concentration for all countries, while the change in average plant size, $\triangle$ LPS, has an expected positive sign in all five countries and is significant except for Italy.

In sum, we found, most importantly, that the formation of the customs union which was effected by the elimination of protective tariffs walls in the EC member states has led to a more concentrated industry structure. Furthermore, this concentration increasing effect was observed independently from 
the effects of observed changes in total trade exposure which on the contrary decreased national concentration. These two effects are not necessarily conflicting with each other, given that the effects of increases in total trade exposure or increases in both exports and import intensities emphasize the effects caused by the increase in intra-industry trade.

III. The Formation of the Common Market and Changing Market Performance in the Member States.

Having identified the empirical relation between the removal of intra-EC tariffs and changes in seller concentration in the national market, our next task is to examine the relationship between the change in market structure and changes in industry profitability. However, that part of task may not be easy one since the elimination of tariffs not only have increased national concentration but also should have widened the scope of competition geographically. Thus, domestic sellers and foreign sellers now meet and compete with each other in the Common Market. Correspondingly, market performance for each community member would be influenced by the state of community-wide competition, which would not be captured by concentration constructed for the national market.

\section{III-1. Estimation of EEC-Wide Seller Concentration}

In order to capture the effect of the enlarged market on the state of competition, seller concentration on a communitywide basis was estimated. Since detailed accounts on the method of estimation and the estimates of EC-wide concentration are provided elsewhere (Yamawaki, Weiss and Sleuwaegen, 1987), our 
discussion on the construction of EC-wide concentration is minimum here.

The scarcity of data again governed the choice of the estimation method and forced us to adopt an indirect approach which employs industry statistics of the member countries instead of a more direct approach based on largest European firms' sales shares in the EC market. The estimation method used here is based on information on the scale of operation accounted for by the largest firms in each EC country. As in the case of national concentration, we used the number of employment instead of sales as the unit of measurement. The estimation method proceeds as follows:

(1) First estimate, for each of the EC countries, the number of employees in industry controlled by the largest four firms (E4 ${ }_{i j}$ where $i=$ industry and $j=$ country). We estimated it based on the method originated by Bain (1966, pp. 26-29) from data on the firm size distribution by employment size class for the EC countries:

(2) Rank the member countries' E4s in the descending order for each industry. Select the largest E4 for each industry and call this variable as MIN E4. This variable is a minimum estimate of the number of employment controlled by the largest four firms in the Common Market. The assumption behind MIN E4 is that the largest four firms domiciled in a national market whose scale of production jointly exceeds that of the largest firms in any other national market are also appointed as the largest four firms in the Common Market.

(3) From the ranking of the member countries' E4s in each industry, select the top four and add these four to obtain a 
maximum estimate of the number of employment controlled by the largest four firms in the Common Market. We call this variable as MAX E4. It might be based on two alternative assumptions. One possibility would be that the four leading firms in each country belong to a common group of owners. An alternative might be that the leading firm in each of the four countries had the largest market share possible given the national concentration ratio: 15

(4) To obtain minimum and maximum estimates of four-firm concentration in the EC market (MIN EC CR4 and MAX EC CR4, respectively), we divide MIN E4 and MAX E4 by total employment in the Common Market, thus

$$
\text { MIN EC CR4 }=\frac{\text { MIN E4 }}{\text { Total Employment in the Common Market }}
$$

and

$$
\text { MAX EC CR4 }=\frac{\text { MAX E4 }}{\text { Total Employment in the Common Market }}
$$

and

(5) EC-wide concentration is finally obtained by averaging out the minimum estimate and the maximum estimate of concentration obtained in (4),

$$
\text { EC } C R 4=1 / 2(\text { MIN EC CR4 + MAX EC CR4). }
$$

It is essentially arbitrary to assign the mean of the maximum and minimum estimates to EC CR4. It might also introduce bias. Common ownership of leaders in all four countries is surely 
rare, but quite a lot of international mergers involving major firms did occur in the $1960 \mathrm{~s}$ and 1970s. To the extent that this occurred, our estimates of EC CR4 in 1978 are understated relative to the 1963 estimate. Turning to the alternative assumption, market dominance is rare in the United States (Weiss and Pascoe (1984)) but it is likely to be greater in the smaller national markets of Europe. To the extent that the Common Market is much more competitive than a national market would be with trade barriers, the arbitrary downward adjustment that occurs in our procedure is a move in the same direction.

We estimated EC-wide concentration for 1963 and 1978, the only years for which data on the firm size distribution by detailed employment size class are available. ${ }^{16}$ To make the estimate of EC concentration in 1963 comparable to that in 1978 and to eliminate possible distortions associated with the enlargement of the Common Market which occurred after 1973. 1978 employment of Britain, Denmark, and Ireland is subtracted from the denominators of the minimum and maximum estimates of 1978 EC-wide concentration. ${ }^{17}$ Thus the denominators of both 1963 and 1978 EC-wide concentration are defined as the sum of employment in West Germany, France, Italy, the Netherlands and Belgium. 18

\section{III-2. Hypotheses on EC-Wide Concentration}

Previous investigators of the relationship between concentration and industry price-cost margins in the EC countries have assumed that domestic sellers do not recognize their interdependence with foreign sellers ${ }^{19}$ and the relevant market is at the national level even after the formation of the 
EC. Our approach instead allows for the possibility that European firms recognize their interdependence in the Common Market. Based on this line of approach, Yamawaki, Weiss, and sleuwaegen (1987) found some evidence indicating the positive influence of EC-wide concentration on the price-cost margin for larger EC countries, West Germany, France, and Italy.

In the present paper, we extend our earlier analysis and correct possible biases which we might have incurred by treating the coefficient for EC-wide concentration as a constant which does not vary across industries. The major empirical result reported in Yamawaki, Weiss, and sleuwaegen (1987) was obtained on the assumption that the elimination of tariffs within the EC led to a complete integration of national marketrs in every industry. However, this assumption may not hold in some industries because of the existence of regional markets and all sorts of non-tariff barriers to trade. ${ }^{20}$ To the extent that the customs union in the EC is not truely effective, EC-wide concentration would be of relatively less importance in determining the national price-cost margin. Therefore, we propose a research design which retains the information on national concentration treating the change in the national price-cost margin as a function of the change in its national concentration and the change from national to ECwide concentration, weighted by the extent of the integration of national markets. In this way, EC-wide concentration is treated properly as a measure of market structure only in industries where the integration of markets in the EC is effective. 
Our hypothesis is, therefore, that EC-wide concentration is becoming an important structural variable influencing the national price-cost margins in industries where the market is not regionally fragmented, and intra-EC trade is significantly rising. ${ }^{21}$ The theoretical relationship among theories of oligopoly, price-cost margins, and measures of concentration has been presented in recent literature (see, for example, Waterson, 1984), establishing that the price-cost margin is related positively to the measure of concentration.

III-3. Statistical Analysis

\section{Variables}

Our dependent variable is changes in the price-cost margin in the national market. 22

$$
\begin{aligned}
\Delta \mathrm{PCM}= & \operatorname{PCM}(78) / \mathrm{PCM}(63)=\text { Price-cost margins in } 1978 \text { divided } \\
& \text { by price-cost margins in } 1963 \text {. Price-cost margins are } \\
& \text { defined as value added minus payroll divided by value } \\
& \text { of shipments. }
\end{aligned}
$$

As mentioned above, we use two measures of concentration:

$$
\begin{aligned}
\triangle N C R 4= & N C R 4(78)-N C R 4(63)=\text { Difference between the four- } \\
& \text { firm national concentration ratio (NCR4) in } 1978 \text { and } \\
& \text { that in } 1963 ; \text { and }
\end{aligned}
$$

$\triangle E C N C R 4=\operatorname{EC~CR4}(78)-\operatorname{NCR} 4(63)=$ Difference between the fourfirm EC concentration ratio (EC CR4) in 1978 and the four-firm national concentration ratio in 1963. 
$\triangle N C R 4$ measures the change in national concentration, while $\triangle E C N C R 4$ measures the change from national concentration to ECwide concentration. As shown in table 1 , the sample mean for $\triangle E C N C R 4$ decreases with the size of national market, reflecting the higher level of national concentration in smaller EC countries.

These two measures of changes in concentration are used interactively with exogenous variables to test whether the effect of changes in concentration varies with the extent of market integration within the EC. Certain products which are subject to high shipping costs cannot economically be transported far from the country of production even after the Common Market's formation, and so they are primarily sold in regionally fragmented markets. In the existence of local markets, concentration measured at the Common Market level will understate effective concentration, and concentration measured at the national market will provide more accurate state of competition. Thus, we introduce

$$
\begin{aligned}
R E G D= & \text { Dummy variable equal to one if the market is judged } \\
& \text { to be regionally fragmented in the U.S. counterpart } \\
& \text { industry. } 23
\end{aligned}
$$

Since a measure of the extent of market segregation within the EC is not easily obtainable, we construct REGD based on the experience in the U.S. assuming that if the market is regionally fragmented in U.S. industries, the Common Market counterparts would also experience similar tendency due to common technological characteristics associated with the 
products. We include the two interaction variables in the model; $\triangle N C R 4$ * REGD to represent fragmented markets; and $\triangle E C N C R 4$ * (1 - REGD) to represent integrated markets.

In addition to REGD, we introduce a dummy variable which distinguishes industries where intra-EC exports increased significantly during the 1963-78 period from those which did not:

$$
\begin{aligned}
\text { LOECXD = } & \text { Dummy variable equal to one if the change in } \\
& \text { intra-EC export intensity between } 1963 \text { and } 1978 \text { is } \\
& \text { less than } 0.1 \text {. Intra-EC export intensity is } \\
& \text { measured as the ratio of total intra-EC exports } \\
& \text { from west Germany, France, Italy, and Belgium to } \\
& \text { total world exports from these countries. }
\end{aligned}
$$

The sample mean of the change in intra-EC export intensity is 0.12 and ranges between -0.16 and 0.59 . Twenty-one industries in our sample are assigned to LOECXD, and the rest of the industries where intra-EC export intensity grew more than 108 point between 1963 and 1978 are assigned to HIECXD = (1LOECXD). Thus, the interactive terms are defined as $\triangle \mathrm{NCR} 4$ * LOECXD and $\triangle E C N C R 4$ * HIECXD.

other variables included in the model are:

$$
\begin{aligned}
\triangle D E P S L= & \operatorname{DEPSL}(75) / \operatorname{DEPSL}(63)=\text { The depreciation-sales ratio } \\
& (\text { DEPSL) in } 1975 \text { divided by the ratio in } 1963 ;
\end{aligned}
$$




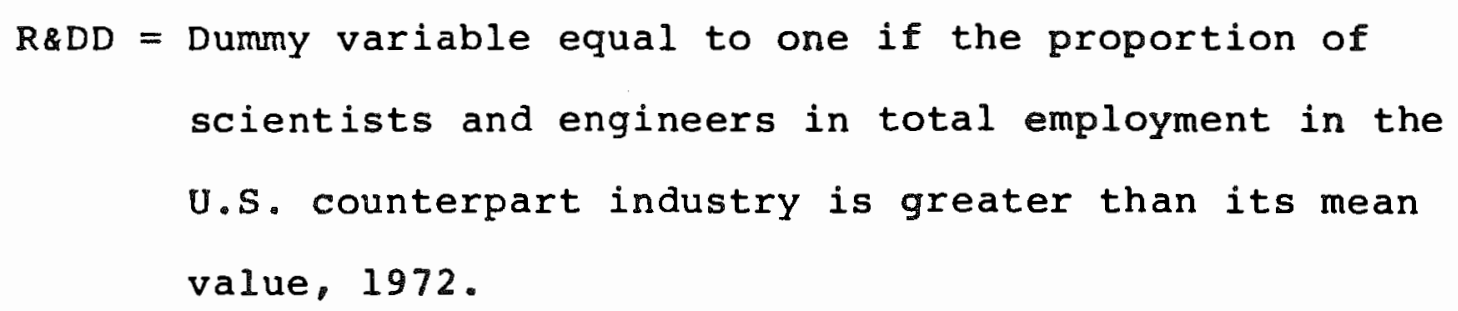

$\triangle D E P S L$ is included to control for changes in gross returns to capital included in the numerator of the price-cost margin. Unfortunately, the capital-sales ratio which has been used conventionally in previous literature is not available for the EC countries. R\&DD is expected to control for the effect of long-run industry structural change or industry evolution which might have occurred over the period and affected intertemporal behavior of price-cost margins.

Finally, for the equations in France, Italy, Belgium and the Netherlands, changes in the price-cost margin in west Germany $\left(\triangle \mathrm{PCM}_{\mathrm{GER}}\right)$ are included to test whether industries in these four EC countries behave as price-takes and follow the price set by the west German industries. ${ }^{25}$ In addition, this variable may control for other industry specific disturbances common to the Common Market countries.

Our basic model to identify the effect of changes in concentration on changes in the price-cost margin is:

$$
\begin{aligned}
\triangle P C M= & b_{0}+b_{1} \triangle N C R 4 * D+b_{2} \triangle E C N C R 4 *(1-D) \\
& +b_{3} \triangle D E P S L+b_{4} R \& D D+e
\end{aligned}
$$

where $e$ is the random error, and $D$ is a dummy variable to identify industries where market intergration is not effective (represented by either REGD or LOECXD). In this speicifcation, 
the effect of concentration varies across industries according to the extent of market integration represented by $D$.

\section{Statistical Results}

Table 3 presents the OLS result of equation (2) with the concentration variables interacted with REGD for each of the five EC countries. As mentioned above, $\triangle P C M_{G E R}$ is added to the equation for France, Italy, Belgium, and the Netherlands. $\triangle \mathrm{ECNCR} 4$ * (1-REG) is significant at the 5 percent level and has an expected positive coefficient for West Germany, France, and italy, while it is not significant for Belgium and the Netherlands. This result confirms the result of Yamawaki, Weiss, and Sleuwaegen (1987) that in larger EC countries the formation of the Common Market has affected their national price-cost-margins through its effect on effective concentration. The result in table 3 suggests that for west Germany, France, and Italy, the effect of EC-wide concentration is increasingly important in industries where the market is not regionally fragmented.

On the contrary, $\triangle N C R 4$ * REGD is not signifiant in all countries except France where it is weakly significant and has a positive coefficient. Thus, the result again reinforces the above finding that EC-wide concentration is becoming a more important market structure after the formation of the common Market.

In table 4 , the oLS regression using the concentration variables interacted with LOECXD and HIECXD is reported for larger EC countries. To capture the total effect of changing trade exposures, the equations in table 4 include additionally 
changes in export intensity ( $\Delta W X S$ ) and changes in import intensity (DWMS). For West Germany, France, and Italy, ECNCR4 * HIECXD is significant and has a positive coefficient, 26 implying that EC-wide concentration is increasingly important as a determinant of the national price-cost margin in industries where intra-EC export intensity rises significantly. $\triangle N C R 4$ * LOECXD is not significant in all of the three countries. This result is consistent with the result in table 3 and reinforces our conclusion that, for larger EC countries EC-wide concentration is becoming an important structural variable influencing their national price-cost margins in industries where EC integration has been more effective.

\section{Summary and Conclusions}

The main purposes of this paper were to examine the effect of the elimination of intra-EC tariffs on changes in national concentration, and to test whether EC-wide concentration is becoming an important structural variable in determining the national price-cost margin. The statistical analysis found, first, that the formation of the Common Market has created a more concentrated industry structure in the national market for West Germany, France, Italy, and Belgium. Secondly, the regression analysis found that EC-wide concentration rather than national concentration is becoming important in determining the national price-cost margin in industries where the market is geographically integrated, and the importance of intra-community trade has been increasing.

Thus, the route that the removal of intra-EC tariffs has affected the national price-cost margin is not through 
increasing national concentration but through enlarging the effective size of market beyond national boundaries and therefore enhancing the possibility that domestic firms form oligopolistic interdependence with foreign firms. The largest firms from West Germany, France, and Italy may have recognized mutual dependence after the creation of the Common Market. Thus, an important direction of future research on competition in the EC countries is to consider in more detail the influence of oligopolistic interdependence across national boundaries. 


\section{FOOTWOTES}

1 For a description of the Common Market, see Swann (1984).

2 See, for example, Kreinin (1974). Mayes (1978) provides a survey on the literature.

3 For example, Balassa (1966) and Grubel (1967).

4 For a detailed discussion on this hypothesis and its test using the US data, see Caves (1985). See also Scitovsky (1958) and Owen (1983). Some empirical attempts have been made on this aspect using the data for the European countries, see Owen (1983), and Müller and Owen (1985).

5 See Swann (1984), Table 4, p. 95. the cumulative tariff reduction effected by July 1963 was 608 .

6 See Caves (1985). Also see Caves and Porter (1980), and Geroski and Masson (1987).

7 The 1963 Census uses the NICE classification, while the 1978 data follow the NACE classification. However, the concordance between these two systems is perfect.

8 For a detailed discussion on the estimation method, see Bain (1966), pp. 26-29.

9 Concentration measured in employment may understate true concentration because less concentrated industries and smaller plants are commonly more labor-intensive than large plants and concentration industries.

10 For a justification to include both the tariff and trade exposure variables in the model, see Caves (1985).

11 For some evidence on the interactive effect of changes in the size of efficient-scale plants and industry growth on changes in concentration, see Caves and Porter (1980).

12 Due to missing observations, the sample size for the Netherlands is 39. For the rest of the countries, the sample size is 47 . Luxemburg is excluded from the estimation due to missing data. Thus, Luxemburg is totally omitted from the analysis in this paper.

13 Caves (1985) finds, for the United States, a similar concentration increasing effect of tariff reductions in the 1958-77 period. He shows simultaneously that these tariff reductions are related to a decrease in the number of plants.

14 Pelkmans (1984, pp. 244-245) puts it: "...at present the EC has several thousands of Member-State-Specific textile and clothing quotas, rendering the internal "free customs union" in this sector ridiculous, ....." 
15 On this point, see Yamawaki, Weiss and Sleuwaegen (1987).

16 Unpublished data prepared by the Statistical office of the European Communities were used for 1978 .

17 It is true that British firms may be among the four leaders in the EC. But in most cases that will not change concentration much because the British firm is likely to be displacing a continental firm with only a bit smaller size.

18 Employment of Luxembourg is not included in the denominators for both 1963 and 1978 .

19 The exception is a study by Auquier (1977).

20 For example, see Pelkmans (1984) and Franko (1976), ch.6.

21 Some preliminary result based on this approach is reported in Yamawaki, Weiss, and Sleuwaegen (1987).

22 For a previous study on the determinants of changes in price-cost margins, see Cowling and Waterson (1976).

23 These include clay products (NACE 241), concrete and cement products (243), meat products (412), dairy products (413), bakery products (19), brewing (427), soft drinks (428), and printing (473). The choice was made based on Weiss (1972), Appendix, and Schwartzman and Bodoff (1971), Table II. Meat products and brewing industries are included to take into account the characteristics in the EEC countries.

24 For France, even data on depreciation are not obtainable. We therefore used the ratio of gross investment to sales averaged over a five-year period for France.

25 For detailed discussions on the hypothesis, see Yamawaki, Weiss, and sleuwaegen (1987). Kervyn (1979) observes that West German manufacturing industry acts as a price leader. For an approach using the rival country's PCM in explaining the national PCM, see Yamawaki (1986).

26 For Belgium and the Netherlands, $\triangle$ ECNCR4 * HIECXD was not significant. $\triangle D E P S L$ was eliminated from the specification in table 4 to save the degree of freedom after the variable was found to be insignificant for West Germany, France, and Italy. 
References

Auquier, Antoine A., 1977, Industrial Organization in an Opening Economy: French Industry and the Formation of the European Common Market, Ph.D. Dissertation, Harvard University.

Bain, Joe S., 1966, International Difference in Industrial Structure: Eight Nations in the $1950^{\prime} \mathrm{s}$ (New Haven: Yale University Press).

Balassa, Bela, 1966, "Tariff Reduction and Trade in Manufacturers among the Industrial Countries," American Economic Review 56 (June), pp. 466-473.

Balassa, Bela, 1975, "Introduction: The Common Market Experience" in B. Balassa (ed.), European Economic Integration (Amsterdam: North-Hol land).

Caves, Richard E., 1985, "Trade Exposure and Changing Structures of U.S. Manufacturing Industries," Harvard Institute of Economic Research, Harvard University. Discussion Paper No. 1154 (May).

Caves, Richard E. and Michael E. Porter, 1980, "The Dynamics of Changing Seller Concentration," Journal of Industrial Economics 29 (September), pp. 1- 15.

Cowling, Keith and Michael Waterson, 1976, "Price-Cost Margins and Market Structure," Economica 43 (August), pp. 267-274.

Franko, Lawrence G., 1976, The European Multinationals: A Renewed Challenge to American and British Big Business (London: Harper \& Row).

George, Kenneth D. and T.S. Ward, 1975. The Structure of Industry in the EEC: An International Comparison (Cambridge: Cambridge University Press).

Geroski, P.A., and R.T. Masson, 1987 "Dynamic Market Models in Industrial Organization," International Journal of Industrial Organization 5 (March), pp. 1-13.

Grubel, Herbert G., 1967, "Intra-Industry Specialization and the Pattern of Trade," Canadian Journal of Economics and Political science 33 (August), pp. 374-388.

Jacquemin, Alexis and Andre Sapir, 1987, "Intra-EC Trade: A Sectoral Analysis," Center for European Policy Studies, Brussels, CEPS Working Documents 24 (January).

Kervyn de Lettenhove, A., 1979, "Taux de change, inflation et competitivite externe," Recherches Economiques de Louvain 45, pp. 55-94.

Kreinin, Mordechai E., 1974, Trade Relations of the EEC: An Empirical Investigation (New York: Praeger). 
Lyons, Bruce R., 1981, "Industrial Behavior, the Technology of Demand, and the Pattern of International Trade Between Identical Countries," Recherches Economigues de Louvain 44 (September), pp. 243-258.

Mayes, David G., 1978, "The Effects of Economic Integration on Trade," Journal of Common Market Studies 17

(September), pp. 1-25.

Müller, Jürgen and Nicholas Owen, 1985, "The Effect of Trade on Plant Size," in J. Schwalbach (ed.), Industry Structure and Performance (Berlin: Edition Sigma).

Owen, Nicholas, 1983, Economies of Scale, Competitiveness and Trade Patterns within the European Community loxford: oxford University Press).

Pelkmans, Jacques, 1984 , Market Integration in the European Community (The Hague: Martinus Nijhoff).

Phlips, Louis, 1971, Effects of Industrial Concentration: A Cross-Section Analysis for the Common Market

(Amsterdam: North-Holland).

Scitovsky, Tibor, 1958, Economic Theory and Western European Integration (London: Allen and Unwin).

Schwartzman, David and Joan Bodoff, 1971, "Concentration in Regional and Local Industries," Southern Economic Journal 37 (January), pp. 343-348.

Swann, Dennis, 1984, The Economics of the Common Market, 5th ed. (Harmondsworth, England: Penguin Books).

Waterson, Michael, 1984, Economic Theory of the Industry (Cambridge: Cambridge University Press).

Weiss, Leonard W., 1972, "The Geographic Size of Markets in Manufacturing," Review of Economics and Statistics 54 (August), pp. 245-257.

Weiss, Leonard $W$. and George Pascoe, 1984, "The Extent and Permanence of Market Dominance," International Institute of Management, Berlin, IIM/IP Discussion Paper 84-23 (July).

Yamawaki, Hideki, 1986, "Exports, Foreign Market Structure, and Profitability in Japanese and U.S. Manufacturing," Review of Economics and Statistics 68 (November), Pp. 618-627.

Yamawaki, Hideki, Leonard W. Weiss, and Leo Sleuwaegen, 1987, "Industry Competition and the Formation of the European Common Market," forthcoming in L.W. Weiss (ed.), Price and Concentration (Cambridge, MA: MIT Press). 
Table 1: Means and Standard Deviations

\begin{tabular}{|c|c|c|c|c|c|}
\hline Variable & $\begin{array}{l}\text { West Germany } \\
(\mathrm{N}=47)\end{array}$ & $\begin{array}{c}\text { France } \\
(N=47)\end{array}$ & $\begin{array}{c}\text { Italy } \\
(\mathrm{N}=47)\end{array}$ & $\begin{array}{l}\text { Belgium } \\
(\mathrm{N}=47)\end{array}$ & $\begin{array}{l}\text { The Netherlands } \\
\begin{aligned}(*: \mathbf{N}=30) \\
(*: \mathbf{N}=39)\end{aligned}\end{array}$ \\
\hline$\triangle N C R 4$ & $\begin{array}{c}0.041 \\
(0.072)\end{array}$ & $\begin{array}{c}0.082 \\
(0.134)\end{array}$ & $\begin{array}{c}0.063 \\
(0.096)\end{array}$ & $\begin{array}{c}0.052 \\
(0.148)\end{array}$ & $\begin{array}{c}0.041 \\
(0.136)\end{array}$ \\
\hline ALNCR4 & $\begin{array}{c}0.278 \\
(0.494)\end{array}$ & $\begin{array}{c}0.397 \\
(0.535)\end{array}$ & $\begin{array}{c}0.359 \\
(0.566)\end{array}$ & $\begin{array}{c}0.188 \\
(0.404)\end{array}$ & $\begin{array}{l}0.127 \star \star \\
(0.422)\end{array}$ \\
\hline$\triangle \mathrm{ECNCR} 4$ & $\begin{array}{l}-0.004 \\
(0.074)\end{array}$ & $\begin{array}{l}-0.039 \\
(0.093)\end{array}$ & $\begin{array}{l}-0.035 \\
(0.108)\end{array}$ & $\begin{array}{l}-0.181 \\
(0.172)\end{array}$ & $\begin{array}{l}-0.148 * \\
(0.185)\end{array}$ \\
\hline$\triangle \mathrm{PCM}$ & $\begin{array}{c}0.271 \\
(0.084)\end{array}$ & $\begin{array}{c}0.327 \\
(0.105)\end{array}$ & $\begin{array}{c}0.265 \\
(0.082)\end{array}$ & $\begin{array}{c}0.295 \\
(0.185)\end{array}$ & $\begin{array}{r}0.207 * \\
(0.099)\end{array}$ \\
\hline$\triangle D E P S L$ & $\begin{array}{c}1.091 \\
(0.346)\end{array}$ & $\begin{array}{c}1.216 \\
(0.588)\end{array}$ & $\begin{array}{c}0.961 \\
(0.502)\end{array}$ & $\begin{array}{c}0.979 \\
(0.486)\end{array}$ & $\begin{array}{l}1.140^{*} \\
(0.650)\end{array}$ \\
\hline$\Delta W X S$ & $\begin{array}{c}0.112 \\
(0.107)\end{array}$ & $\begin{array}{c}0.136 \\
(0.188)\end{array}$ & $\begin{array}{c}0.189 \\
(0.378)\end{array}$ & $\begin{array}{l}-0.034 \\
(1.575)\end{array}$ & $\begin{array}{l}0.213 \star \\
(0.407)\end{array}$ \\
\hline$\triangle W M S$ & $\begin{array}{c}0.122 \\
(0.130)\end{array}$ & $\begin{array}{c}0.139 \\
(0.181)\end{array}$ & $\begin{array}{l}-0.138 \\
(1.129)\end{array}$ & $\begin{array}{c}0.011 \\
(1.242)\end{array}$ & $\begin{array}{r}0.168^{\star} \\
(0.246)\end{array}$ \\
\hline$\triangle T A R I F F$ & $\begin{array}{c}0.084 \\
(0.037)\end{array}$ & $\begin{array}{c}0.221 \\
(0.078)\end{array}$ & $\begin{array}{c}0.185 \\
(0.076)\end{array}$ & $\begin{array}{c}0.127 \\
(0.089)\end{array}$ & $\begin{array}{l}0.054 * \star \\
(0.015)\end{array}$ \\
\hline$\triangle$ LEMP & $\begin{array}{l}-0.389 \\
(0.436)\end{array}$ & $\begin{array}{l}-0.186 \\
(0.602)\end{array}$ & $\begin{array}{l}-0.162 \\
(0.728)\end{array}$ & $\begin{array}{l}-0.216 \\
(0.475)\end{array}$ & $\begin{array}{l}-0.404 * \hbar \\
(0.607)\end{array}$ \\
\hline$\triangle \mathrm{LPS}$ & $\begin{array}{c}0.063 \\
(0.436)\end{array}$ & $\begin{array}{c}0.210 \\
(0.256)\end{array}$ & $\begin{array}{c}0.019 \\
(0.260)\end{array}$ & $\begin{array}{l}-0.080 \\
(0.400)\end{array}$ & $\begin{array}{l}-0.124 * * \\
(0.373)\end{array}$ \\
\hline
\end{tabular}

Notes: Entries show means and standard deviations in parentheses. $\triangle$ DEPSI for France is not comparable with that for other countries due to the difference in the definitions. The operator $I$ is used to indicate a variable expressed in the logarithm. 
Table 2-A: Regression Equations Explaining Changes in Concentration for 1963-78 $(\triangle$ LNCR4) for West Germany $(N=47)$

\begin{tabular}{|c|c|c|c|c|c|c|}
\hline \multirow{2}{*}{$\begin{array}{l}\text { Independent } \\
\text { Variables }\end{array}$} & \multicolumn{2}{|c|}{ No restriction } & \multicolumn{2}{|c|}{ on the coefficient } & \multicolumn{2}{|c|}{$\begin{array}{l}\text { Restriction on the trade } \\
\text { exposure coefficients }\end{array}$} \\
\hline & 1 & 2 & 3 & 4 & 5 & 6 \\
\hline LNCR4 (63) & $\begin{array}{l}-0.294 \\
(3.04)\end{array}$ & $\begin{array}{l}-0.338 \\
(3.57)\end{array}$ & $\begin{array}{l}-0.239 \\
(2.41)\end{array}$ & $\begin{array}{l}-0.287 \\
(2.87)\end{array}$ & $\begin{array}{l}-0.239 \\
(2.44)\end{array}$ & $\begin{array}{l}-0.287 \\
(2.91)\end{array}$ \\
\hline$\triangle$ LEMP & $\begin{array}{l}-0.473 \\
(3.21)\end{array}$ & $\begin{array}{l}-0.486 \\
(3.45)\end{array}$ & $\begin{array}{l}-0.611 \\
(3.76)\end{array}$ & $\begin{array}{l}-0.596 \\
(3.77)\end{array}$ & $\begin{array}{l}-0.610 \\
(3.84)\end{array}$ & $\begin{array}{l}-0.592 \\
(3.83)\end{array}$ \\
\hline$\triangle$ LPS & $\begin{array}{l}0.199 \\
(1.48)\end{array}$ & $\begin{array}{r}0.209 \\
(1.63)\end{array}$ & $\begin{array}{l}0.175 \\
(1.28)\end{array}$ & $\begin{array}{l}0.184 \\
(1.38)\end{array}$ & $\begin{array}{l}0.178 \\
(1.37)\end{array}$ & $\begin{array}{l}0.191 \\
(1.51)\end{array}$ \\
\hline$\triangle W X S$ & & & $\begin{array}{l}-0.546 \\
(0.83)\end{array}$ & $\begin{array}{l}-0.364 \\
(0.56)\end{array}$ & $\begin{array}{r}-0.592 \\
(1.94)\end{array}$ & $\begin{array}{l}-0.468 \\
(1.54)\end{array}$ \\
\hline$\triangle W M S$ & & & $\begin{array}{l}-0.637 \\
(0.96)\end{array}$ & $\begin{array}{l}-0.571 \\
(0.89)\end{array}$ & $\begin{array}{r}-0.592 \\
(1.94)\end{array}$ & $\begin{array}{r}-0.468 \\
(1.54)\end{array}$ \\
\hline$\triangle$ TARIFF & & $\begin{array}{r}4.506 \\
(2.17)\end{array}$ & & $\begin{array}{r}3.805 \\
(1.79)\end{array}$ & & $\begin{array}{c}3.783 \\
(1.81)\end{array}$ \\
\hline$C D$ & $\begin{array}{r}0.161 \\
(1.12)\end{array}$ & $\begin{array}{r}-0.002 \\
(0.01)\end{array}$ & $\begin{array}{c}0.193 \\
(1.34)\end{array}$ & $\begin{array}{r}0.051 \\
(0.32)\end{array}$ & $\begin{array}{r}0.191 \\
(1.36)\end{array}$ & $\begin{array}{r}0.048 \\
(0.30)\end{array}$ \\
\hline Dl & $\begin{array}{r}0.547 \\
(1.31)\end{array}$ & $\begin{array}{r}0.390 \\
(0.96)\end{array}$ & $\begin{array}{c}0.458 \\
(1.10)\end{array}$ & $\begin{array}{r}0.351 \\
(0.86)\end{array}$ & $\begin{array}{r}0.453 \\
(1.12)\end{array}$ & $\begin{array}{c}0.340 \\
(0.85)\end{array}$ \\
\hline D2 & $\begin{array}{c}0.368 \\
(1.80)\end{array}$ & $\begin{array}{r}0.568 \\
(2.63)\end{array}$ & $\begin{array}{r}0.301 \\
(1.48)\end{array}$ & $\begin{array}{r}0.483 \\
(2.18)\end{array}$ & $\begin{array}{c}0.302 \\
(1.50)\end{array}$ & $\begin{array}{r}0.483 \\
(2.20)\end{array}$ \\
\hline D3 & $\begin{array}{r}0.203 \\
(1.18)\end{array}$ & $\begin{array}{r}0.265 \\
(1.59)\end{array}$ & $\begin{array}{c}0.153 \\
(0.90)\end{array}$ & $\begin{array}{r}0.214 \\
(1.27)\end{array}$ & $\begin{array}{r}0.155 \\
(0.92)\end{array}$ & $\begin{array}{r}0.217 \\
(1.30)\end{array}$ \\
\hline Constant & $\begin{array}{r}-0.672 \\
(2.64)\end{array}$ & $\begin{array}{c}-1.114 \\
(3.51)\end{array}$ & $\begin{array}{r}-0.457 \\
(1.67)\end{array}$ & $\begin{array}{c}-0.876 \\
(2.48)\end{array}$ & $\begin{array}{r}-0.457 \\
(1.69)\end{array}$ & $\begin{array}{r}-0.873 \\
(2.50)\end{array}$ \\
\hline $\mathbf{R}^{2}$ & 0.47 & 0.52 & 0.49 & 0.52 & 0.51 & 0.53 \\
\hline $\mathbf{F}$ & 6.87 & 7.18 & 5.98 & 6.02 & 6.91 & 6.87 \\
\hline
\end{tabular}

Notes: $t$-values are in parentheses. Significance levels for one-tailed $t(40)$ are 1 percent $=2.42,5$ percent $=1.68$, and 10 percent $=1.30$. 
Table 2-B: Regression Equations Explaining Changes in Concentration for 1963-78 ( $\triangle$ LNCR4) for France (Full Sample: $N=47$ )

\begin{tabular}{|c|c|c|c|c|c|c|}
\hline \multirow{2}{*}{$\begin{array}{l}\text { Independent } \\
\text { Variables }\end{array}$} & \multicolumn{2}{|c|}{ No restriction on } & \multicolumn{2}{|c|}{ the coefficlent } & \multicolumn{2}{|c|}{$\begin{array}{l}\text { Restriction on the trade } \\
\text { exposure coefficients }\end{array}$} \\
\hline & 1 & 2 & 3 & 4 & 5 & 6 \\
\hline LNCR4 (63) & $\begin{array}{l}-0.307 \\
(3.66)\end{array}$ & $\begin{array}{l}-0.309 \\
(3.73)\end{array}$ & $\begin{array}{l}-0.278 \\
(3.33)\end{array}$ & $\begin{array}{l}-0.277 \\
(3.40)\end{array}$ & $\begin{array}{l}-0.277 \\
(3.26)\end{array}$ & $\begin{array}{l}-0.277 \\
(3.31)\end{array}$ \\
\hline$\triangle$ LEMP & $\begin{array}{l}-0.240 \\
(2.15)\end{array}$ & $\begin{array}{l}-0.236 \\
(2.14)\end{array}$ & $\begin{array}{l}-0.446 \\
(2.91)\end{array}$ & $\begin{array}{l}-0.464 \\
(3.10)\end{array}$ & $\begin{array}{r}-0.415 \\
(2.63)\end{array}$ & $\begin{array}{l}-0.425 \\
(2.74)\end{array}$ \\
\hline$\triangle \mathrm{LPS}$ & $\begin{array}{l}0.468 \\
(1.67)\end{array}$ & $\begin{array}{r}0.503 \\
(1.80)\end{array}$ & $\begin{array}{l}0.395 \\
(1.43)\end{array}$ & $\begin{array}{l}0.427 \\
(1.58)\end{array}$ & $\begin{array}{r}0.417 \\
(1.50)\end{array}$ & $\begin{array}{r}0.451 \\
(1.65)\end{array}$ \\
\hline$\Delta$ WXs & & & $\begin{array}{l}0.744 \\
(0.71)\end{array}$ & $\begin{array}{l}0.730 \\
(0.72)\end{array}$ & $\begin{array}{l}-0.368 \\
(1.54)\end{array}$ & $\begin{array}{l}-0.397 \\
(1.69)\end{array}$ \\
\hline$\triangle W M S$ & & & $\begin{array}{l}-1.663 \\
(1.53)\end{array}$ & $\begin{array}{l}-1.751 \\
(1.66)\end{array}$ & $\begin{array}{l}-0.368 \\
(1.54)\end{array}$ & $\begin{array}{r}-0.397 \\
(1.69)\end{array}$ \\
\hline$\triangle T A R I F F$ & & $\begin{array}{l}1.353 \\
(1.39)\end{array}$ & & $\begin{array}{c}1.608 \\
(1.72)\end{array}$ & & $\begin{array}{c}1.482 \\
(1.56)\end{array}$ \\
\hline$C D$ & $\begin{array}{r}0.137 \\
(1.10)\end{array}$ & $\begin{array}{c}0.158 \\
(0.88)\end{array}$ & $\begin{array}{r}0.205 \\
(1.17)\end{array}$ & $\begin{array}{c}0.160 \\
(0.93)\end{array}$ & $\begin{array}{c}0.216 \\
(1.23)\end{array}$ & $\begin{array}{c}0.174 \\
(0.39)\end{array}$ \\
\hline Dl & $\begin{array}{c}0.329 \\
(0.67)\end{array}$ & $\begin{array}{r}0.575 \\
(1.11)\end{array}$ & $\begin{array}{c}0.270 \\
(0.56)\end{array}$ & $\begin{array}{r}0.551 \\
(1.11)\end{array}$ & $\begin{array}{c}0.256 \\
(0.52)\end{array}$ & $\begin{array}{r}0.518 \\
(1.02)\end{array}$ \\
\hline D2 & $\begin{array}{r}0.046 \\
(0.18)\end{array}$ & $\begin{array}{r}0.073 \\
(0.29)\end{array}$ & $\begin{array}{r}0.009 \\
(0.04)\end{array}$ & $\begin{array}{l}0.040 \\
(0.17)\end{array}$ & $\begin{array}{c}0.037 \\
(0.15)\end{array}$ & $\begin{array}{r}0.067 \\
(0.27)\end{array}$ \\
\hline D3 & $\begin{array}{l}0.142 \\
(0.69)\end{array}$ & $\begin{array}{r}0.054 \\
(0.25)\end{array}$ & $\begin{array}{c}0.090 \\
(0.42)\end{array}$ & $\begin{array}{r}-0.012 \\
(0.06)\end{array}$ & $\begin{array}{c}0.187 \\
(0.91)\end{array}$ & $\begin{array}{r}0.095 \\
(0.45)\end{array}$ \\
\hline Constant & $\begin{array}{c}-0.445 \\
(1.52)\end{array}$ & $\begin{array}{r}-0.718 \\
(2.06)\end{array}$ & $\begin{array}{c}-0.273 \\
(0.92)\end{array}$ & $\begin{array}{r}-0.581 \\
(1.71)\end{array}$ & $\begin{array}{r}-0.337 \\
(1.14)\end{array}$ & $\begin{array}{r}-0.627 \\
(1.82)\end{array}$ \\
\hline$R^{2}$ & 0.39 & 0.40 & 0.42 & 0.45 & 0.41 & 0.43 \\
\hline $\mathbf{F}$ & 5.12 & 4.83 & 4.74 & 4.79 & 4.93 & 4.82 \\
\hline
\end{tabular}

Notes: $t$-values are in parentheses. Significance levels for one-tailed $t(40)$ are 1 percent $=2.42,5$ percent $=1.68$, and 10 percent $=1.30$. 
Table 2-C: Regression Equations Explaining Changes in Concentration for 1963-78 ( $\triangle \mathrm{LNCR} 4$ ) for France (excluding textiles and clothing industries: $N=43$ )

\begin{tabular}{|c|c|c|c|c|c|c|c|}
\hline \multirow{2}{*}{$\begin{array}{l}\text { Independent } \\
\text { Variables }\end{array}$} & \multicolumn{3}{|c|}{ No restriction on } & \multicolumn{2}{|c|}{ the coefficient } & \multicolumn{2}{|c|}{$\begin{array}{l}\text { Restriction on the trade } \\
\text { exposure coefficients }\end{array}$} \\
\hline & 1 & 2 & & 3 & 4 & 5 & 6 \\
\hline INCRA (63) & $\begin{array}{l}-0.308 \\
(3.49)\end{array}$ & $\begin{array}{r}-0.337 \\
(4.10)\end{array}$ & & $\begin{array}{l}-0.278 \\
(3.03)\end{array}$ & $\begin{array}{l}-0.310 \\
(3.85)\end{array}$ & $\begin{array}{l}-0.265 \\
(2.96)\end{array}$ & $\begin{array}{l}-0.292 \\
(3.57)\end{array}$ \\
\hline$\triangle$ LEMP & $\begin{array}{r}-0.313 \\
(2.93)\end{array}$ & $\begin{array}{l}-0.314 \\
(3.18)\end{array}$ & & $\begin{array}{l}-0.498 \\
(3.28)\end{array}$ & $\begin{array}{l}-0.512 \\
(3.88)\end{array}$ & $\begin{array}{l}-0.498 \\
(3.32)\end{array}$ & $\begin{array}{l}-0.512 \\
(3.76)\end{array}$ \\
\hline$\triangle$ LPS & $\begin{array}{r}0.278 \\
(1.02)\end{array}$ & $\begin{array}{r}0.315 \\
(1.25)\end{array}$ & & $\begin{array}{l}0.245 \\
(0.90)\end{array}$ & $\begin{array}{l}0.274 \\
(1.15)\end{array}$ & $\begin{array}{r}0.221 \\
(0.83)\end{array}$ & $\begin{array}{l}0.255 \\
(1.05)\end{array}$ \\
\hline$\Delta$ WXS & & & & $\begin{array}{l}0.812 \\
(0.81)\end{array}$ & $\begin{array}{l}0.869 \\
(0.99)\end{array}$ & $\begin{array}{l}-0.382 \\
(1.71)\end{array}$ & $\begin{array}{r}-0.409 \\
(2.02)\end{array}$ \\
\hline$\triangle W M S$ & & & & $\begin{array}{l}-1.669 \\
(1.54)\end{array}$ & $\begin{array}{l}-1.777 \\
(1.93)\end{array}$ & $\begin{array}{r}-0.382 \\
(1.71)\end{array}$ & $\begin{array}{r}-0.409 \\
(2.02)\end{array}$ \\
\hline$\triangle T A R I F F$ & & $\begin{array}{r}2.383 \\
(2.67)\end{array}$ & & & $\begin{array}{c}2.558 \\
(3.03)\end{array}$ & & $\begin{array}{c}2.462 \\
(2.87)\end{array}$ \\
\hline$C D$ & $\begin{array}{r}0.324 \\
(1.82)\end{array}$ & $\begin{array}{r}0.312 \\
(1.90)\end{array}$ & & $\begin{array}{r}0.305 \\
(1.69)\end{array}$ & $\begin{array}{r}0.299 \\
(1.93)\end{array}$ & $\begin{array}{r}0.329 \\
(1.90)\end{array}$ & $\begin{array}{r}0.317 \\
(2.01)\end{array}$ \\
\hline Dl & $\begin{array}{c}0.296 \\
(0.63)\end{array}$ & $\begin{array}{r}0.778 \\
(1.66)\end{array}$ & & $\begin{array}{l}0.246 \\
(0.53)\end{array}$ & $\begin{array}{c}0.765 \\
(1.72)\end{array}$ & $\begin{array}{r}0.195 \\
(0.42)\end{array}$ & $\begin{array}{r}0.687 \\
(1.53)\end{array}$ \\
\hline D2 & $\begin{array}{r}0.051 \\
(0.21)\end{array}$ & $\begin{array}{r}0.134 \\
(0.60)\end{array}$ & & $\begin{array}{c}0.012 \\
(0.05)\end{array}$ & $\begin{array}{c}0.101 \\
(0.48)\end{array}$ & $\begin{array}{c}0.028 \\
(0.12)\end{array}$ & $\begin{array}{c}0.112 \\
(0.52)\end{array}$ \\
\hline D3 & $\begin{array}{r}0.071 \\
(0.36)\end{array}$ & $\begin{array}{r}-0.070 \\
(0.37)\end{array}$ & & $\begin{array}{c}0.025 \\
(0.12)\end{array}$ & $\begin{array}{r}-0.131 \\
(0.69)\end{array}$ & $\begin{array}{r}0.107 \\
(0.55)\end{array}$ & $\begin{array}{r}-0.036 \\
(0.20)\end{array}$ \\
\hline Constant & $\begin{array}{r}-0.389 \\
(1.31)\end{array}$ & $\begin{array}{r}-0.929 \\
(2.73)\end{array}$ & & $\begin{array}{c}-0.230 \\
(0.75)\end{array}$ & $\begin{array}{r}-0.802 \\
(2.46)\end{array}$ & $\begin{array}{r}-0.247 \\
(0.82)\end{array}$ & $\begin{array}{r}-0.795 \\
(2.39)\end{array}$ \\
\hline $\mathrm{R}^{2}$ & 0.46 & 0.54 & & 0.49 & 0.59 & 0.49 & 0.58 \\
\hline $\mathbf{F}$ & 6.12 & 7.18 & & 5.32 & 7.10 & 6.02 & 7.41 \\
\hline
\end{tabular}

Notes: $t$-values are in parentheses. Significance levels for one-tailed $t(30)$ are 1 percent $=2.46,5$ percent $=1.70$, and 10 percent $=1.31$. 
Table 2-D: Regression Equations Explaining Changes in Concentration for 1963-78 ( $\triangle L N C R 4)$ for Italy $(N=47)$

\begin{tabular}{|c|c|c|c|c|c|c|}
\hline \multirow{2}{*}{$\begin{array}{l}\text { Independent } \\
\text { Variables }\end{array}$} & \multicolumn{2}{|c|}{ No restriction } & \multicolumn{2}{|c|}{ the coefficient } & \multicolumn{2}{|c|}{$\begin{array}{l}\text { Restriction on the trade } \\
\text { exposure coefficients }\end{array}$} \\
\hline & 1 & 2 & 3 & 4 & 5 & 6 \\
\hline LNCR4 (63) & $\begin{array}{l}-0.266 \\
(2.74)\end{array}$ & $\begin{array}{l}-0.304 \\
(3.04)\end{array}$ & $\begin{array}{l}-0.313 \\
(3.38)\end{array}$ & $\begin{array}{l}-0.340 \\
(3.58)\end{array}$ & $\begin{array}{l}-0.307 \\
(3.28)\end{array}$ & $\begin{array}{l}-0.334 \\
(3.47)\end{array}$ \\
\hline$\triangle$ LEMP & $\begin{array}{l}-0.320 \\
(2.32)\end{array}$ & $\begin{array}{l}-0.290 \\
(2.09)\end{array}$ & $\begin{array}{l}-0.455 \\
(3.32)\end{array}$ & $\begin{array}{l}-0.424 \\
(3.05)\end{array}$ & $\begin{array}{l}-0.423 \\
(3.08)\end{array}$ & $\begin{array}{l}-0.392 \\
(2.81)\end{array}$ \\
\hline$\triangle$ LPS & $\begin{array}{r}0.649 \\
(2.02)\end{array}$ & $\begin{array}{r}0.635 \\
(2.00)\end{array}$ & $\begin{array}{l}0.602 \\
(2.00)\end{array}$ & $\begin{array}{r}0.594 \\
(1.99)\end{array}$ & $\begin{array}{l}0.603 \\
(1.98)\end{array}$ & $\begin{array}{r}0.595 \\
(1.96)\end{array}$ \\
\hline$\Delta$ wXS & & & $\begin{array}{l}-0.984 \\
(1.99)\end{array}$ & $\begin{array}{l}-0.971 \\
(1.97)\end{array}$ & $\begin{array}{l}-0.303 \\
(2.39)\end{array}$ & $\begin{array}{l}-0.284 \\
(2.22)\end{array}$ \\
\hline$\Delta W M S$ & & & $\begin{array}{l}0.253 \\
(0.62)\end{array}$ & $\begin{array}{l}0.278 \\
(0.68)\end{array}$ & $\begin{array}{l}-0.303 \\
(2.39)\end{array}$ & $\begin{array}{l}-0.284 \\
(2.22)\end{array}$ \\
\hline$\triangle$ TARIFF & & $\begin{array}{l}1.359 \\
(1.37)\end{array}$ & & $\begin{array}{l}1.086 \\
(1.15)\end{array}$ & & $\begin{array}{l}1.070 \\
(1.12)\end{array}$ \\
\hline$C D$ & $\begin{array}{r}0.206 \\
(1.09)\end{array}$ & $\begin{array}{r}0.122 \\
(0.62)\end{array}$ & $\begin{array}{l}0.317 \\
(1.75)\end{array}$ & $\begin{array}{l}0.244 \\
(1.28)\end{array}$ & $\begin{array}{r}0.296 \\
(1.61)\end{array}$ & $\begin{array}{l}0.224 \\
(1.16)\end{array}$ \\
\hline Dl & $\begin{array}{l}-0.248 \\
(0.49)\end{array}$ & $\begin{array}{l}-0.276 \\
(0.55)\end{array}$ & $\begin{array}{l}-0.288 \\
(0.60)\end{array}$ & $\begin{array}{l}-0.313 \\
(0.66)\end{array}$ & $\begin{array}{r}-0.212 \\
(0.44)\end{array}$ & $\begin{array}{l}-0.237 \\
(0.49)\end{array}$ \\
\hline D2 & $\begin{array}{l}0.097 \\
(0.39)\end{array}$ & $\begin{array}{l}0.098 \\
(0.40)\end{array}$ & $\begin{array}{l}0.286 \\
(1.14)\end{array}$ & $\begin{array}{r}0.285 \\
(1.14)\end{array}$ & $\begin{array}{r}0.149 \\
(0.63)\end{array}$ & $\begin{array}{r}0.146 \\
(0.62)\end{array}$ \\
\hline D3 & $\begin{array}{r}0.219 \\
(1.05)\end{array}$ & $\begin{array}{r}0.214 \\
(1.03)\end{array}$ & $\begin{array}{r}0.351 \\
(1.66)\end{array}$ & $\begin{array}{r}0.347 \\
(1.65)\end{array}$ & $\begin{array}{r}0.237 \\
(1.20)\end{array}$ & $\begin{array}{c}0.232 \\
(1.18)\end{array}$ \\
\hline Constant & $\begin{array}{c}-0.422 \\
(1.59)\end{array}$ & $\begin{array}{c}-0.703 \\
(2.11)\end{array}$ & $\begin{array}{c}-0.508 \\
(2.04)\end{array}$ & $\begin{array}{r}-0.729 \\
(2.33)\end{array}$ & $\begin{array}{c}-0.478 \\
(1.90)\end{array}$ & $\begin{array}{c}-0.696 \\
(2.19)\end{array}$ \\
\hline $\mathrm{R}^{2}$ & 0.38 & 0.39 & 0.46 & 0.46 & 0.45 & 0.45 \\
\hline $\mathbf{F}$ & 5.00 & 4.71 & 5.35 & 4.99 & 5.62 & 5.17 \\
\hline
\end{tabular}

Notes: $t$-values are in parentheses. Significance levels for one-tailed $t(40)$ are 1 percent $=2.42,5$ percent $=1.68$, and 10 percent $=1.30$. 
Table 2-E: Regression Equations Explaining Changes in Concentration for 1963-78 ( $\triangle L N C R 4)$ for Belgium $(N=47)$

\begin{tabular}{|c|c|c|c|c|c|c|}
\hline \multirow{2}{*}{$\begin{array}{l}\text { Independent } \\
\text { Variables }\end{array}$} & \multicolumn{2}{|c|}{ No restriction } & \multicolumn{2}{|c|}{ the coefficient } & \multicolumn{2}{|c|}{$\begin{array}{l}\text { Restriction on the trade } \\
\text { exposure coefficients }\end{array}$} \\
\hline & 1 & 2 & 3 & 4 & 5 & 6 \\
\hline LNCR4 (63) & $\begin{array}{l}-0.330 \\
(4.02)\end{array}$ & $\begin{array}{l}-0.351 \\
(4.38)\end{array}$ & $\begin{array}{l}-0.289 \\
(3.50)\end{array}$ & $\begin{array}{l}-0.304 \\
(3.77)\end{array}$ & $\begin{array}{l}-0.356 \\
(4.37)\end{array}$ & $\begin{array}{l}-0.371 \\
(4.65)\end{array}$ \\
\hline$\triangle$ LEMP & $\begin{array}{l}-0.171 \\
(1.35)\end{array}$ & $\begin{array}{l}-0.195 \\
(1.58)\end{array}$ & $\begin{array}{l}-0.186 \\
(1.55)\end{array}$ & $\begin{array}{l}-0.201 \\
(1.71)\end{array}$ & $\begin{array}{r}-0.215 \\
(1.71)\end{array}$ & $\begin{array}{l}-0.230 \\
(1.87)\end{array}$ \\
\hline$\triangle$ LPS & $\begin{array}{l}0.125 \\
(0.93)\end{array}$ & $\begin{array}{l}0.180 \\
(1.35)\end{array}$ & $\begin{array}{r}0.187 \\
(1.46)\end{array}$ & $\begin{array}{l}0.226 \\
(1.79)\end{array}$ & $\begin{array}{r}0.184 \\
(1.35)\end{array}$ & $\begin{array}{r}0.224 \\
(1.67)\end{array}$ \\
\hline$\Delta w X S$ & & & $\begin{array}{l}-0.929 \\
(2.62)\end{array}$ & $\begin{array}{l}-0.901 \\
(2.61)\end{array}$ & $\begin{array}{l}-0.151 \\
(1.74)\end{array}$ & $\begin{array}{l}-0.131 \\
(1.53)\end{array}$ \\
\hline$\triangle$ WMS & & & $\begin{array}{l}0.624 \\
(1.77)\end{array}$ & $\begin{array}{l}0.638 \\
(1.86)\end{array}$ & $\begin{array}{r}-0.151 \\
(1.74)\end{array}$ & $\begin{array}{l}-0.131 \\
(1.53)\end{array}$ \\
\hline$\triangle$ TARIFF & & $\begin{array}{l}1.202 \\
(1.93)\end{array}$ & & $\begin{array}{l}1.045 \\
(1.79)\end{array}$ & & $\begin{array}{l}1.072 \\
(1.74)\end{array}$ \\
\hline$C D$ & $\begin{array}{r}0.333 \\
(2.66)\end{array}$ & $\begin{array}{l}0.299 \\
(2.44)\end{array}$ & $\begin{array}{l}0.409 \\
(3.44)\end{array}$ & $\begin{array}{l}0.375 \\
(3.21)\end{array}$ & $\begin{array}{r}0.352 \\
(2.88)\end{array}$ & $\begin{array}{r}0.319 \\
(2.64)\end{array}$ \\
\hline Dl & $\begin{array}{r}0.539 \\
(1.30)\end{array}$ & $\begin{array}{r}0.365 \\
(0.89)\end{array}$ & $\begin{array}{r}0.435 \\
(1.13)\end{array}$ & $\begin{array}{l}0.294 \\
(0.77)\end{array}$ & $\begin{array}{r}0.470 \\
(1.16)\end{array}$ & $\begin{array}{r}0.324 \\
(0.80)\end{array}$ \\
\hline$D 2$ & $\begin{array}{r}0.377 \\
(2.06)\end{array}$ & $\begin{array}{r}0.446 \\
(2.47)\end{array}$ & $\begin{array}{r}0.311 \\
(1.81)\end{array}$ & $\begin{array}{r}0.372 \\
(2.18)\end{array}$ & $\begin{array}{r}0.371 \\
(2.08)\end{array}$ & $\begin{array}{c}0.433 \\
(2.44)\end{array}$ \\
\hline D3 & $\begin{array}{c}0.455 \\
(3.10)\end{array}$ & $\begin{array}{r}0.510 \\
(3.52)\end{array}$ & $\begin{array}{c}0.482 \\
(3.51)\end{array}$ & $\begin{array}{c}0.531 \\
(3.90)\end{array}$ & $\begin{array}{r}0.445 \\
(3.11)\end{array}$ & $\begin{array}{r}0.496 \\
(3.48)\end{array}$ \\
\hline Constant & $\begin{array}{r}-0.590 \\
(3.45)\end{array}$ & $\begin{array}{c}-0.780 \\
(4.05)\end{array}$ & $\begin{array}{c}-0.522 \\
(3.26)\end{array}$ & $\begin{array}{c}-0.690 \\
(3.80)\end{array}$ & $\begin{array}{l}-0.575 \\
(3.44)\end{array}$ & $\begin{array}{r}-0.747 \\
(3.92)\end{array}$ \\
\hline$\overline{\mathrm{R}}^{2}$ & 0.33 & 0.37 & 0.42 & 0.46 & 0.36 & 0.39 \\
\hline $\mathbf{F}$ & 4.20 & 4.40 & 4.77 & 4.87 & 4.25 & 4.31 \\
\hline
\end{tabular}

Notes: $t$-values are in parentheses. Significance levels for one-tailed $t(40)$ are 1 percent $=2.42,5$ percent $=1.68$, and 10 percent $=1.30$. 
Table 2-F: Regression Equations Explaining Changes in Concentration for 1963-78 ( $\triangle$ LNCR4) for the Netherlands ( $N=39$ )

\begin{tabular}{|c|c|c|c|c|c|c|}
\hline \multirow{2}{*}{$\begin{array}{l}\text { Independent } \\
\text { Variables }\end{array}$} & \multicolumn{4}{|c|}{ No restriction on the coefficient } & \multicolumn{2}{|c|}{$\begin{array}{l}\text { Restriction on the trade } \\
\text { exposure coefficients }\end{array}$} \\
\hline & 1 & 2 & 3 & 4 & 5 & 6 \\
\hline LNCR4 (63) & $\begin{array}{l}-0.314 \\
(3.25)\end{array}$ & $\begin{array}{l}-0.330 \\
(3.17)\end{array}$ & $\begin{array}{l}-0.290 \\
(2.79)\end{array}$ & $\begin{array}{l}-0.298 \\
(2.85)\end{array}$ & $\begin{array}{l}-0.283 \\
(2.79)\end{array}$ & $\begin{array}{l}-0.292 \\
(2.86)\end{array}$ \\
\hline$\triangle$ LEMP & $\begin{array}{l}-0.181 \\
(1.67)\end{array}$ & $\begin{array}{l}-0.207 \\
(1.84)\end{array}$ & $\begin{array}{l}-0.352 \\
(2.58)\end{array}$ & $\begin{array}{l}-0.359 \\
(2.62)\end{array}$ & $\begin{array}{l}-0.351 \\
(2.61)\end{array}$ & $\begin{array}{l}-0.358 \\
(2.65)\end{array}$ \\
\hline$\Delta$ LPS & $\begin{array}{r}0.566 \\
(2.90)\end{array}$ & $\begin{array}{r}0.694 \\
(3.08)\end{array}$ & $\begin{array}{r}0.578 \\
(2.90)\end{array}$ & $\begin{array}{r}0.663 \\
(3.00)\end{array}$ & $\begin{array}{r}0.582 \\
(2.96)\end{array}$ & $\begin{array}{r}0.670 \\
(3.09)\end{array}$ \\
\hline$\Delta$ WXS & & & $\begin{array}{l}-0.149 \\
(0.46)\end{array}$ & $\begin{array}{l}-0.154 \\
(0.47)\end{array}$ & $\begin{array}{l}-0.297 \\
(2.05)\end{array}$ & $\begin{array}{l}-0.274 \\
(1.86)\end{array}$ \\
\hline$\triangle$ WMS & & & $\begin{array}{l}-0.484 \\
(1.22)\end{array}$ & $\begin{array}{l}-0.428 \\
(1.06)\end{array}$ & $\begin{array}{l}-0.297 \\
(2.05)\end{array}$ & $\begin{array}{l}-0.274 \\
(1.86)\end{array}$ \\
\hline$\triangle$ TARIFF & & $\begin{array}{l}-5.712 \\
(1.22)\end{array}$ & & $\begin{array}{l}-4.159 \\
(0.90)\end{array}$ & & $\begin{array}{l}-4.354 \\
(0.96)\end{array}$ \\
\hline$C D$ & $\begin{array}{r}0.122 \\
(0.83)\end{array}$ & $\begin{array}{l}0.134 \\
(0.89)\end{array}$ & $\begin{array}{r}0.091 \\
(0.60)\end{array}$ & $\begin{array}{r}0.102 \\
(0.67)\end{array}$ & $\begin{array}{r}0.077 \\
(0.53)\end{array}$ & $\begin{array}{r}0.091 \\
(0.62)\end{array}$ \\
\hline DI & $\begin{array}{r}0.769 \\
(1.68)\end{array}$ & $\begin{array}{l}0.928 \\
(1.91)\end{array}$ & $\begin{array}{l}0.893 \\
(1.90)\end{array}$ & $\begin{array}{l}0.978 \\
(2.03)\end{array}$ & $\begin{array}{r}0.844 \\
(1.86)\end{array}$ & $\begin{array}{r}0.942 \\
(2.02)\end{array}$ \\
\hline D2 & $\begin{array}{r}0.087 \\
(0.44)\end{array}$ & $\begin{array}{r}0.044 \\
(0.21)\end{array}$ & $\begin{array}{l}0.003 \\
(0.01)\end{array}$ & $\begin{array}{l}-0.023 \\
(0.11)\end{array}$ & $\begin{array}{r}0.000 \\
(0.00)\end{array}$ & $\begin{array}{c}-0.026 \\
(0.13)\end{array}$ \\
\hline D3 & $\begin{array}{c}0.108 \\
(0.65)\end{array}$ & $\begin{array}{c}0.213 \\
(1.14)\end{array}$ & $\begin{array}{c}0.138 \\
(0.84)\end{array}$ & $\begin{array}{r}0.207 \\
(1.13)\end{array}$ & $\begin{array}{c}0.132 \\
(0.82)\end{array}$ & $\begin{array}{r}0.206 \\
(1.15)\end{array}$ \\
\hline Constant & $\begin{array}{c}-0.413 \\
(2.15)\end{array}$ & $\begin{array}{c}-0.156 \\
(0.52)\end{array}$ & $\begin{array}{c}-0.310 \\
(1,50)\end{array}$ & $\begin{array}{c}-0.121 \\
(0.41)\end{array}$ & $\begin{array}{l}-0.299 \\
(1.48)\end{array}$ & $\begin{array}{c}-0.104 \\
(0.36)\end{array}$ \\
\hline $\mathrm{R}^{2}$ & 0.32 & 0.32 & 0.35 & 0.35 & 0.37 & 0.37 \\
\hline $\boldsymbol{F}$ & 3.58 & 3.19 & 3.31 & 3.04 & 3.79 & 3.46 \\
\hline
\end{tabular}

Notes: $t$-values are in parentheses. Significance levels for one-tailed $t(30)$ are 1 percent $=2.46,5$ percent $=1.70$, and 10 percent $=1.31$. 
Table 3 Regression Equations Explaining Changes in Price-Cost Margins ( $\triangle$ PCM) with Changes in Concentrations Adjusted for Geographic Extent of Market.

\begin{tabular}{|c|c|c|c|c|c|c|c|c|}
\hline \multirow[b]{2}{*}{ Country } & \multirow[b]{2}{*}{$\begin{array}{l}\text { Equation } \\
\text { Number }\end{array}$} & \multicolumn{6}{|c|}{ I $n d e p e n d e n t \quad V$ a $r$ i $a b l e$} & \multirow{2}{*}{$\begin{array}{l}\overline{\mathrm{R}}^{2} \\
\mathrm{~F}\end{array}$} \\
\hline & & $\triangle \mathrm{NCR} 4$ * REGD & $\begin{array}{l}\triangle \mathrm{ECNCR} 4 \\
\star(1-\mathrm{REGD})\end{array}$ & $\triangle \mathrm{DEPSL}$ & $\mathrm{R} \& \mathrm{DD}$ & $\triangle \mathrm{PCM}_{\mathrm{GER}}$ & Constant & \\
\hline \multirow[t]{2}{*}{$\begin{array}{l}\text { West Germany } \\
(N=47)\end{array}$} & 1 & $\begin{array}{l}-0.036 \\
(0.121)\end{array}$ & $\begin{array}{c}0.429 \\
(2.240)\end{array}$ & $\begin{array}{l}-0.004 \\
(0.108)\end{array}$ & $\begin{array}{l}-0.056 \\
(2.161)\end{array}$ & & $\begin{array}{c}0.299 \\
(7.116)^{a}\end{array}$ & $\begin{array}{l}0.177 \\
3.480^{b}\end{array}$ \\
\hline & 2 & $\begin{array}{l}-0.043 \\
(0.151)\end{array}$ & $\begin{array}{c}0.419 \\
(2.506)^{a}\end{array}$ & & $\begin{array}{l}-0.057 \\
(2.321)\end{array}$ & & $\begin{array}{c}0.295 \\
(20.69)^{a}\end{array}$ & $\begin{array}{l}0.196 \\
4.745^{a}\end{array}$ \\
\hline \multirow[t]{2}{*}{$\begin{array}{l}\text { France } \\
(N=47)\end{array}$} & 3 & $\begin{array}{l}0.239 \\
(1.327)\end{array}$ & $\begin{array}{l}0.282 \\
(1.693)\end{array}$ & $\begin{array}{l}-0.003 \\
(0.092)\end{array}$ & $\begin{array}{c}0.040 \\
(1.111)\end{array}$ & $\begin{array}{c}0.481 \\
(2.605)^{a}\end{array}$ & $\begin{array}{c}0.192 \\
(2.824)^{a}\end{array}$ & $\begin{array}{l}0.146 \\
2.574\end{array}$ \\
\hline & 4 & $\begin{array}{l}0.241 \\
(1.357)\end{array}$ & $\begin{array}{c}0.279 \\
(1.732)\end{array}$ & & $\begin{array}{c}0.041 \\
(1.235)\end{array}$ & $\begin{array}{c}0.480 \\
(2.634)^{a}\end{array}$ & $\begin{array}{c}0.188 \\
(3.342)^{a}\end{array}$ & $\begin{array}{l}0.166 \\
3.293^{b}\end{array}$ \\
\hline \multirow[t]{2}{*}{$\begin{array}{l}\text { Italy } \\
(N=47)\end{array}$} & 5 & $\begin{array}{l}-0.244 \\
(1.216)\end{array}$ & $\begin{array}{c}0.276 \\
(2.262)^{b}\end{array}$ & $\begin{array}{c}0.010 \\
(0.421)\end{array}$ & $\begin{array}{c}0.043 \\
(1.603)\end{array}$ & $\begin{array}{l}0.282 \\
(1.927)^{b}\end{array}$ & $\begin{array}{c}0.178 \\
(3.729)^{a}\end{array}$ & $\begin{array}{l}0.143 \mathrm{~b} \\
2.532^{b}\end{array}$ \\
\hline & 6 & $\begin{array}{l}-0.026 \\
(1.162)\end{array}$ & $\begin{array}{l}0.273 \\
(2.262)^{b}\end{array}$ & & $\begin{array}{l}0.044 \\
(1.697)\end{array}$ & $\begin{array}{c}0.288 \\
(2.002)^{b}\end{array}$ & $\begin{array}{c}0.184 \\
(4.139)^{a}\end{array}$ & $\begin{array}{l}0.160 \mathrm{~b} \\
3.183^{\mathrm{b}}\end{array}$ \\
\hline \multirow[t]{2}{*}{$\begin{array}{l}\text { Belgium } \\
(\mathrm{N}=47)\end{array}$} & 7 & $\begin{array}{c}0.001 \\
(0.001)\end{array}$ & $\begin{array}{c}0.152 \\
(0.895)\end{array}$ & $\begin{array}{l}-0.046 \\
(0.802)\end{array}$ & $\begin{array}{c}0.134 \\
(2.080)\end{array}$ & $\begin{array}{l}0.803 \\
(2.245)^{b}\end{array}$ & $\begin{array}{c}0.106 \\
(0.904)\end{array}$ & $\begin{array}{l}0.071 \\
1.698\end{array}$ \\
\hline & 8 & $\begin{array}{l}-0.081 \\
(0.140)\end{array}$ & $\begin{array}{c}0.172 \\
(1.025)\end{array}$ & & $\begin{array}{l}0.124 \\
(1.971) \mathrm{cc}\end{array}$ & $\begin{array}{c}0.739 \\
(2.128)^{b}\end{array}$ & $\begin{array}{c}0.086 \\
(0.754)\end{array}$ & $\begin{array}{l}0.078 \\
1.978\end{array}$ \\
\hline \multirow[t]{2}{*}{$\begin{array}{l}\text { The Netherlands } \\
(N=30)\end{array}$} & 9 & $\begin{array}{c}0.264 \\
(0.830)\end{array}$ & $\begin{array}{l}-0.121 \\
(1.191)\end{array}$ & $\begin{array}{c}0.067 \\
(2.528)^{a}\end{array}$ & $\begin{array}{l}-0.046 \\
(1.073)\end{array}$ & $\begin{array}{c}0.286 \\
(1.309)\end{array}$ & $\begin{array}{c}0.048 \\
(0.588)\end{array}$ & $\begin{array}{l}0.187 \\
2.333^{c}\end{array}$ \\
\hline & 10 & $\begin{array}{c}0.251 \\
(0.715)\end{array}$ & $\begin{array}{l}-0.122 \\
(1.085)\end{array}$ & & $\begin{array}{l}-0.032 \\
(0.684)\end{array}$ & $\begin{array}{c}0.195 \\
(0.821)\end{array}$ & $\begin{array}{c}0.145 \\
(1.830)^{b}\end{array}$ & $\begin{array}{l}0.012 \\
1.086\end{array}$ \\
\hline
\end{tabular}

Notes: $t$-values are in parentheses. Levels of significance in one-tailed tests are: a = 1 percent, $b=5$ percent, and $c=10$ percent. A two-tailed test is applied to the coefficient on R\&DD, and its significance level is designated by double superscripts. 
Table 4: Regression Equations Explaining Change in Price-Cost Margins ( $\triangle \mathrm{PCM}$ ) with Changes in Concentrations Adjusted for Changes in the Extent of Intra-EEC Exports

\begin{tabular}{|c|c|c|c|}
\hline $\begin{array}{l}\text { Independent } \\
\text { Variable }\end{array}$ & $\begin{array}{l}\text { West Germany } \\
\text { (1) }\end{array}$ & $\begin{array}{l}\text { France } \\
\text { (2) }\end{array}$ & $\begin{array}{l}\text { Italy } \\
\text { (3) }\end{array}$ \\
\hline$\triangle \mathrm{NCR} 4$ * LOECXD & $\begin{array}{c}0.128 \\
(0.626)\end{array}$ & $\begin{array}{c}0.164 \\
(0.971)\end{array}$ & $\begin{array}{l}-0.067 \\
(0.390)\end{array}$ \\
\hline$\triangle E C N C R 4$ * HIECXD & $\begin{array}{c}0.555 \\
(2.400)^{b}\end{array}$ & $\begin{array}{l}0.352 \\
(1.510)^{c}\end{array}$ & $\begin{array}{c}0.421 \\
(2.766)^{a}\end{array}$ \\
\hline$\Delta$ WXS & $\begin{array}{c}0.257 \\
(1.995)^{b}\end{array}$ & $\begin{array}{l}-0.063 \\
(0.238)\end{array}$ & $\begin{array}{l}-0.030 \\
(0.922)\end{array}$ \\
\hline$\triangle$ WMS & $\begin{array}{l}-0.044 \\
(0.405)\end{array}$ & $\begin{array}{l}-0.043 \\
(0.172)\end{array}$ & $\begin{array}{c}0.005 \\
(0.445)\end{array}$ \\
\hline$R \& D D$ & $\begin{array}{l}-0.055 \\
(2.299)\end{array}$ & $\begin{array}{c}0.040 \\
(0.961)\end{array}$ & $\begin{array}{l}0.063 \\
(2.309)^{\mathrm{bb}}\end{array}$ \\
\hline$\triangle \mathrm{PCM}_{\mathrm{GER}}$ & & $\begin{array}{c}0.482 \\
(2.398)^{b}\end{array}$ & $\left(\begin{array}{l}0.298 \\
(2.016)^{b}\end{array}\right.$ \\
\hline Constant & $\begin{array}{r}0.262 \\
(14.18)^{a}\end{array}$ & $\begin{array}{c}0.198 \\
(3.142)^{a}\end{array}$ & $\begin{array}{c}0.178 \\
(4.026)^{a}\end{array}$ \\
\hline$\overline{\mathrm{R}}^{2}$ & 0.244 & 0.113 & 0.164 \\
\hline $\mathbf{F}$ & $3.965^{a}$ & $1.975^{\mathrm{C}}$ & $2.503^{b}$ \\
\hline $\mathbf{N}$ & 47 & 47 & 47 \\
\hline
\end{tabular}

Notes: $t$-values are in parentheses.

Levels of significance in one-tailed tests are: $a=1$ percent, $b=5$ percent, and $c=10$ percent.

A two-tailed test is applied to the coefficient on $R \& D$; and its significance level is designated by double superscripts. 


\section{APPENDIX}

Selection of Samples and sources of Data

\section{Selection of Samples}

The classification of industries used in this study is la Nomenclature générale des activitẻs économiques dans les Communautés Européennes (N.A.C.E.) This classification has its origin in la Nomenclature des industries établies dans les Communautés Européennes (N.I.C.E.). The first common market census publishes in 1969 refers to the year 1963 and uses the NICE industry classification system. However, industry statistics publishes in later years follow the NACE classification system. In our analysis we used the NACE classification system as a reference system. Industries from other data sources (Input-Output tables of the EEC countries, trade statistics and the U.S. statistics) were therefore matched to the NACE industries. The level of aggregation used in this study is the NACE 3 -digit level.

Industries used in this study were selected on the basis of information contained in the 1978 employment-size distribution tables of the five countries, which were kindly made available by the statistical office of the European Communities in Luxemburg. The forty-seven industries were thus selected for the analysis.

Sources of Data

Price-cost margins, national concentration, EEC concentration, total employment, and value of total production for 1963:

Office Statistique des Communautés Européennes, Etudes et enquêtes statistiques 2 (Luxemburg: Statistical office of the European Communities (S.O.E.C.), 1969).

Price-cost margins, total employment, and value of total 
production, for 1978 :

Statistical office of the European Communities, Structure and Activity of Industry 1978 (Luxemburg: S.O.E.C., 1983).

The average annual growth ratio in value of production over 1976-78 was constructed from Structure and Activity of Industry, various years. The growth ratio over $1959-65$ and the ratio of depreciation to value of total output were computed from the input-output tables of individual countries:

Statistical Office of the European Communities, Input Output Table (Luxemburg: S.O.E.C.).

The 1978 national concentration for Belgium, France, Italy and West Germany was estimated from the unpublished data on the employment-size classes of enterprises. This information was made available by the statistical office of the European Communities in Luxemburg. National concentration for the Netherlands was provided by Centraal Bureau voor de Statistiek in Voorburg. The number of employees accounted for by the largest four firms in the Netherlands was obtained by dividing the four-firm concentration by total employment. The 1978 EEC concentration is estimated based on the same data base.

Imports and exports for individual countries for 1963 were obtained from:

Statistical Office of the European Communities, Foreign Trade Statistics: Analytical Tables - Imports (Luxemburg: S.O.E.C., 1964).

Statistical office of the European Communities, Foreign Trade Statistics: Analytical Tables - Exports (Luxemburg: S.O.E.C., 1964).

The SITC 4-digit classification used there was converted to the NACE 3-digit classification. Imports and exports for 1978 were obtained from: 
Statistical office of the European Communities, Statistique

du commerce exterieur (Luxemburg: S.O.E.C.).

This information was read from the microfiches coded SCE 2911, NACE-CLIO. For the smaller countries, there were cases where trade intensities exceeded one. In such cases, we constrained the value to one. These were NACE 315 (1963), 451,453,491 for Italy, NACE 491 for Belgium, and NACE 140, 224, and 467 for the Netherlands.

Average plant size for 1978 and 1966 was constructed from:

Statistical office of the European Communities, structure of Earnings: Principal Results 1978/1979, vols. 2, 4, 6, 7, and 8 (Luxemburg: S.O.E.C. 1984); and

Statistical office of the European Communities, Social Statistics (Special series): Survey on the Structure and Distribution of Wages, 1966, vols. 1-8 (Luxemburg: S.O.E.C., 1970).

Average plant size is measured as the average production workers per establishment. For some industries only information at a more aggregated level of industry classification was available.

Import duties for intra-EC traded goods were taken from the harmonized 1959 Input-Output tables for EC member states. For some industries this variable was also available only at a more aggregate level of industrial classification.

The number of scientists and engineers as a proportion of total employment in the U.S. counterpart industry was obtained from:

National Science Foundation, Research and Development in Industry, 1972 (Washington, D.C.: U.S. Government Printing office, 1973). 